\title{
3rd U.S. - JAPAN WORKSHOP ON THE IMPROVEMENT OF BUILDING STRUCTURAL DESIGN AND CONSTRUCTION PRACTICES, 29 JULY-1 AUGUST 1988 TOKYO, JAPAN
}

\author{
I.J. Billings ${ }^{1}$
}

\begin{abstract}
INTRODUCTION
The workshop was held in Tokyo immediately prior to 9 th World Conference on Earthquake Engineering. Two previous workshops have been held in 1984 and 1986 both with an emphasis on seismic building design and construction practices. New Zealand and China were invited to participate in the 3 rd Workshop which was attended by 17 U.S. and 23 Japanese representatives. I was privileged to attend the third workshop which was organised by the Japan Structural Consultants Association. 21 papers were presented covering building seismic analysis and design, and comparison of design codes and practices. The conference concluded with a working session which allowed a useful exchange of information. In the notes below I have summarized several items of particular interest to New zealand practitioners.
\end{abstract}

\section{COMPARISON OF CODES AND DESIGN PRACTICE}

\section{Seismic Force Levels and Drift Limitations}

A Comparison of U.S. and Japanese Codes and the application of these to typical buildings was discussed in several papers. These studies show that for the most active zones seismic force levels used in Japan are typically 2 to 3 times current North American values. In one of the studies [1] a 10 storey ductile moment resisting steel framed building was investigated and the base shear coefficients obtained are given in Table 1 below. The building is sited on 'Soft ground' and the NZ code values have been added for comparison.

\section{Table 1}

Base Shear Coefficients 10 storey Building

$\begin{array}{lll}\text { Japanese Building Code } & 0.145 \mathrm{~g} \\ \text { L.A. City Code } 1980 \text { (USA) } & 0.0439 \\ \text { ATC } 3-06 \text { (USA) } & 0.0629 \\ \text { UBC } 1988 \text { (USA) } & 0.0429 \\ \text { NZS } 4203 & & 0.0539\end{array}$

* Director of Structural Engineering, Beca Carter Hollings \& Ferner Ltd, Auckland.

\begin{abstract}
Interstorey drift limits also vary significantly between the various countries. For the strength level earthquake forces, Japanese codes give values of $1 / 120$ to $1 / 200$ depending on the treatment of secondary damage, while current US codes give drift values in the range of $1 / 200$ to $1 / 400$. NZS 4203 by comparison gives a value of $1 / 310$ where non-structural elements are seismically separated. A useful way of comparing code interstorey drifts is the ratio of design base shear coefficient to the allowable storey drift ratios (CS/R). This comparison was carried out for several buildings in the studies presented at the conference and also compared with the New Zealand Code by the writer. As can be seen above, the Japanese code allows larger interstorey drifts but specifies higher seismic lateral force coefficients than the NZ or US Codes. The net effect is that allowable drift ratios (CS/R) are of a similar order in NZ, US and Japan.
\end{abstract}

The most noticeable difference between the seismic codes of the three countries is the markedly higher seismic coefficients specified by the Japanese codes. This difference was suggested by one Japanese speaker as being a reflection of the four traditional fears of a Japanese (in descending order) - "Earthquake, Fire, Lightning and your old Man" (i.e. your father)! While the strength level lateral earthquake forces differ considerably, it should be noted that the design level earthquake forces implied by both current U.S. and Japanese Codes are based on a peak ground acceleration of around $0.4 \mathrm{~g}$.

\section{Reinforced Concrete Beam/Column Joints}

A comparison of current Beam-Column Joint design methods and philosophies was covered in two papers from Professor Aoyama et al [2] of Japan and from S.K. Ghosh [3] of the U.S.. Professor Aoyama's paper gives a useful comparison of the Japanese Architectural Institute of Japan (AIJ) Concrete code, American concrete Institute (ACI) and New Zealand concrete code NZS3101. Typical figures from his paper are set out in Figures $1-3$.

The requirements of NZS 3101 are significantly more stringent than ACI and these in turn than the AIJ code. The relaxed 

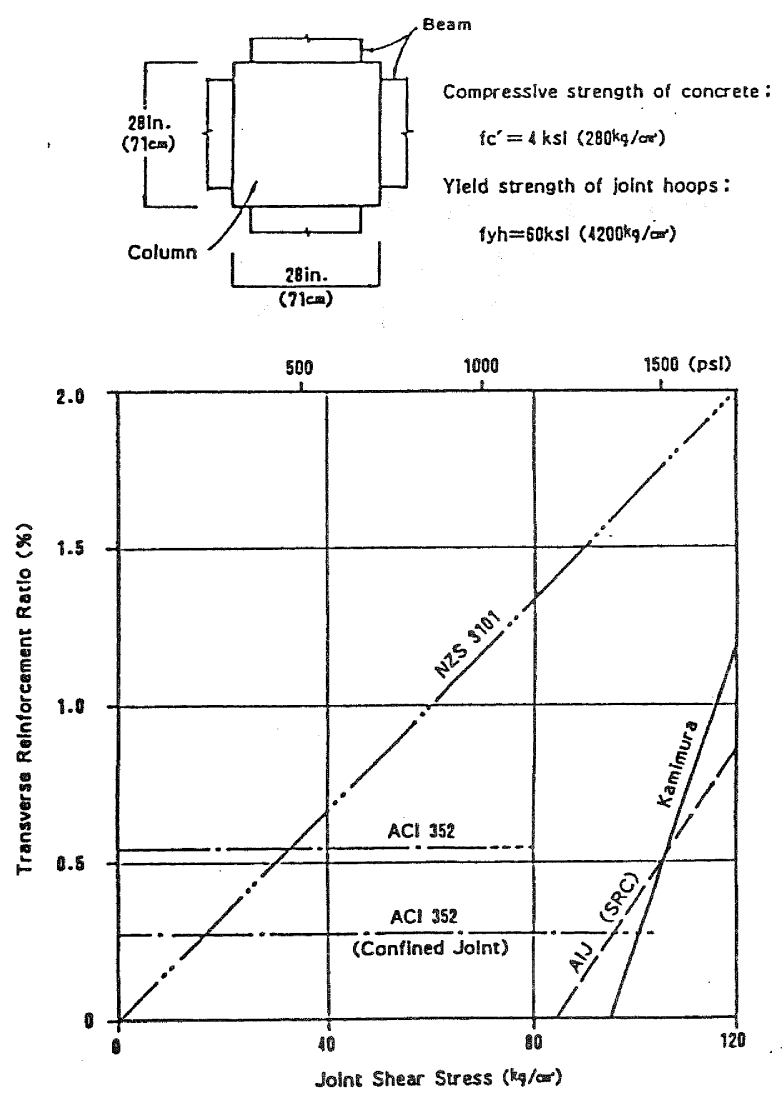

FIGURE 1. REQUIRED RATIO OF JOINT TRANSVERSE REINFORCEMENT
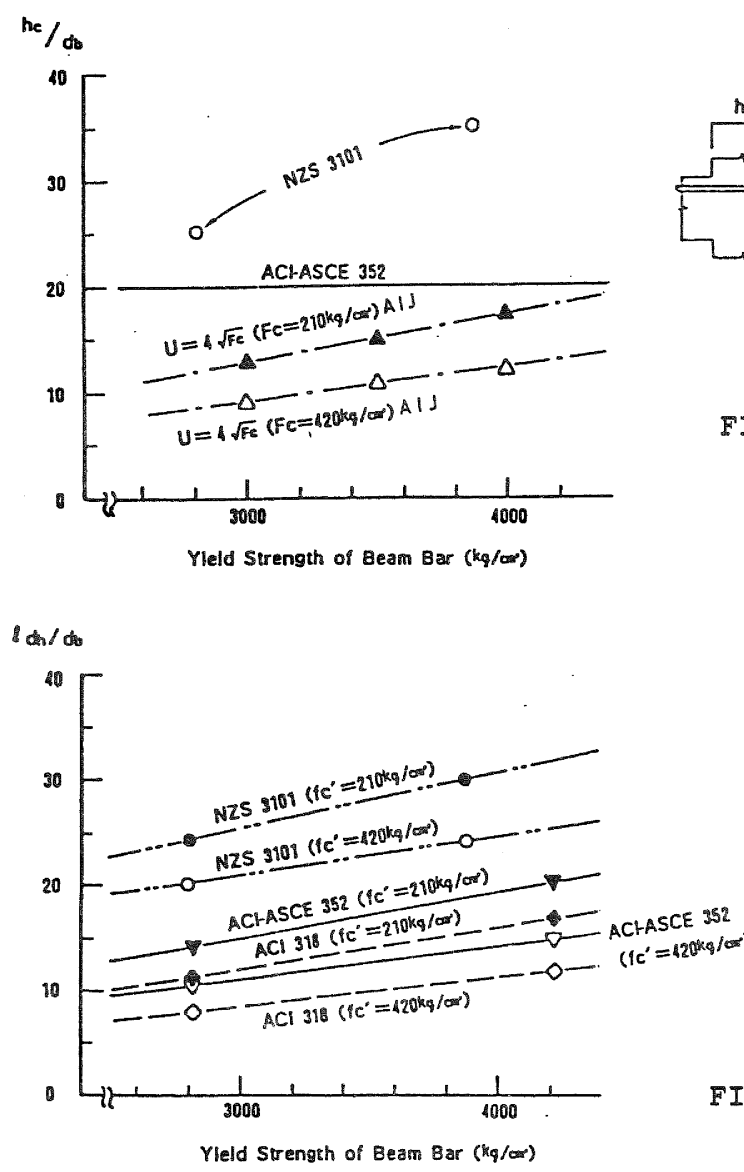

attitude of the AIJ code to beam-column joints apparently reflects the relatively high, strength level earthquake requirements of the Japanese Code. By New Zealand seismic standards, many Japanese structures are essentially imited ductile. Japanese joint design practice is moving closer to that of ACI.

of particular concern to New Zealand is the significant difference between U.S. and NZ practice. For example, U.S. participants noted that NZS3101 implies a joint length/bar diameter ratio $(h / d b)$ ratio of 38 , compared with the ACI value of 20 - a difference of almost 2. A major reason for the difference between some of the design rules lies in the difference of the deformability standards used for testing in the two countries. Several of the U.S. workshop participants noted the ACI view [4] that "the New Zealand approach is based on the performance of statically determinate beam-column sub-assemblies at very large deformation reversals which would correspond to excessive drift values in frame structures." In the U.S., ACI $318-89$ is to be issued shortly and is expected to include a number of relaxations over ACI 318-83. These are described in the paper by Ghosh and include:

- a 25\% reduction to transverse confining steel where rectangular hoops and crossties are used.

- joint steel maximum spacing increased from 100 to $150 \mathrm{~mm}$

- allowing some use of 90 degree bends to anchor cross ties.

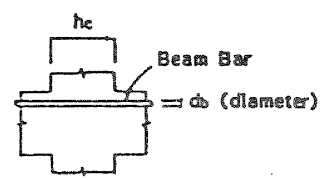

FIGURE 2. REQIREMENTS FOR BEAM BARS PASSING THROUGH JOINTS

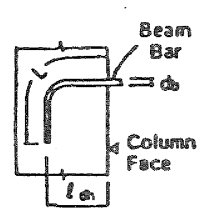

FIGURE 3. HORIZONTAL DEVELOPMENT LENGTH 
The difference in U.S. and NZ joint design practice, with particular reference to deformability standards, will be pursued by the NZNSEE representatives at the 4 th USNZ-Japan-China Collaborative Research Project on R.C. Beam-Column-Slab Joints, in May 1989.

\section{Analysis of Multistorey Buildings}

Interstorey drift calculations are normally carried out by the Japanese on the basis of centre of gravity values whereas U.S. practice is usually to consider the values associated with the worst frame. In making this comparison however, it is to be noted that the treatment of torsion and accidental eccentricity by the respective countries differs significantly. Current U.S. practice is to use an eccentricity of 5 percent.

In the comparison of P-delta effects, usual Japanese practice is to ignore this effect whereas U.S. practice is to include it. This is consistant with the seismic force levels specified in the codes of the two countries.

In Japan, all buildings over 60 metres in height require approval by the Minister of construction and to obtain this, appropriate dynamic analyses are required. In the period since this law was passed in June 1981 until December 1986, 113 buildings primarily in the 60 to 120 metre height range have been dealt with. Since August 1986 designers have been required to follow guidelines requiring:

- Analysis for a strength level earthquake corresponding to a maximum ground velocity of $25 \mathrm{~cm} / \mathrm{sec}$ (approximately equivalent to a peak ground acceleration of $0.2 \mathrm{~g}$ ) in the most active zone.

- Analysis for a design level earthquake corresponding for a maximum ground velocity of $50 \mathrm{~cm} / \mathrm{sec}$ (approximately equivalent to a peak ground acceleration of $0.4 \mathrm{~g}$ ) in the most active zone

- The use of 3 earthquake records selected from appropriate standard earthquake records.

The earthquake records which have been used are primarily El Centro 1940 NS and Taft $1952 \mathrm{EW}$ and these have become standard earthquake records for Japanese high rise analyses. Extensive use has also been made of Tokyo 1956 NS and Hachinohe 1968 NS. Damping factors for the fundamental mode of vibration are generally taken as $2 \%$ for structural steel and $3 \%$ for concrete structures.
BASE ISOLATION AND ENERGY DISSIPATION TECHNIQUES

In both the U.S. and Japan a number of buildings have recently been constructed with base isolators and energy dissipators. In both the U.S. and Japan a substantial amount of research is directed toward this area and the emergence of a number of practical devices is expected in the next few years. In Japan, for example, several of the large corporations are marketing proprietary seismic isolated floors for computer facilities.

\section{CONCLUSION}

The workshop was a useful forum for the exchange of ideas and information in the building earthquake engineering area. While the seismic design philosophies used in the U.S., Japan and New Zealand are now similar there are significant differences which need to be studied. Beam/Column joint design of concrete structures is in this category. Two other impressions remain strong, the large investment in structural (especially aseismic) research and development currently underway in Japan and the superb hospitality of the Japanese.

\section{REFERENCES}

1. T.T. Kaimei \& J.Y. Inoue, "Comparitive study of a 10 storey steel Building designed for U.S. and Japanese Codes", 3 rd U.S. - Japan Workshop on the Improvement of Building structural Design and Construction Practices, Aug. 1988 .

2. H Aoyama, K. Kitayama, Y. Karose \& K. Saida, "Demonstration of Difference between U.S. and Japan Beam Column Joints in R.C. Frames", 3 rd U.S. - Japan Workshop on the Improvement of Building Structural Design and Construction Practices, Aug. 1988.

3. S.K. Ghosh, "Column-Beam Joints to make Ductile R.C. Structure: US code and Design Practice", 3rd U.S. - Japan Workshop on the Improvement of Building structural Design and Construction Practices, Aug 1988.

4. ACI-ASCE Committee 352, "Recommendations for Design of Beam-Column Joints in Monolithic Reinforced Concrete Structures", ACI Journal, Proceeding V.82, No.3, pp266-283, May-June 1985. 